\title{
ON THE PATHOGENIC ACTION OF BLASTOMYCETES.
}

\author{
By Alexander G. R. Foulerton, F.R.C.S., Bacteriologist to the \\ Hiddlesex Hospital.
}

(Plate IV.)

$T_{H E}$ exact study of the pathogenic action of blastomycetes is a comparatively recent branch of pathology. The admirable biochemical investigations with which the names of Pasteur, Hansen, Jorgensen, Duclaux, and many other distinguished continental authorities are associated, have had for their object the better understanding and consequent carrying out by seientific methods of certain industrial processes, such as the fermentation of grape juice, and the brewing of beer. But it has during the last four years become evident that blastomycetes have a wider sphere of action than this, and will in the future have to be considered also as disease producers.

The very earliest experiments bearing on this aspect of their history were apparently those of Claude Bernard (1), who found that rabbits died after receiving an injection of beer yeast and cane sugar solution. In such a case death occurred within three days, with symptoms of gastro-enteritis. Grohe $\left({ }^{2}\right)$, Popoff $\left({ }^{3}\right)$, and Falk ( $\left.{ }^{4}\right)$, carried ont a number of experiments with the view of elucidating the after-history of yeast, when introduced into the living animal. The results of these workers were mainly negative; Falk coming to the conclusion that the injection of pure yeasts, whether into the jugular vein, into a serous cavity, or into the subcutaneous tissue produced no ill results.

Neumayer $\left({ }^{5}\right)$ performed a series of experiments with Sacharomyces apiculatus, S. cerevisice, an alcoholic yeast, and two torulæ. Subcutaneous injection of these, he found, produced no permanent effect. Intravenous injection of large doses caused death with collapse, whilst smaller doses produced little or no effect. Feeding experiments with the yeast alone gave no obvious result, but if at the same time a quantity of a fermentable sugar were added to the animal's diet, an acute gastro-enteritis occurred. Raum $\left(^{(}\right)$carried out a series of inoculation experiments with various yeasts, including, amongst others, S. cerevisice 1, S. ellipsoideus 1 and 2, and S. pastorianus 1. This investigator, like those already mentioned, did not arrive at any very 
diefinite conclusions. On the injection into a vein of large quantities of a culture, lowering of the temperature, collapse, and death followed. In one such case, julmonary embolism caused by the yeast cells, was ohserver. In another case, escape of the yeast cells into the subcutaneous tissue at the site of inoculation was followed ly the revelopment of a solid tumour, which after some three weeks was found to be in a state of caseons degeneration, and still contained yeast cells. These earlier experiments were carriel out for the most part on rabbits, and the conclusions arrived at, as to the comparatively innocuous character of the ordinary culture yeasts, camot, as the experiments which I have myself carried out show, be taken as final.

\section{Bustomycetes I'Athogkxic for Max.}

$\mathrm{U}_{\mathrm{j}}$ to the time of the list of these researches, quoterl above, the only species of blastomyces known to be actually pathogenic for man was S. albicans (vulg. Oidium albicnns), the pimasite of "thansh." This micro-organism has from the time of its discovery by Langenleck in 1839, up to the present day, attracted much attention, both from the botanist and from the patlologist; from the former, hecause of its morphological variations, and from the latter, because of its marked pathogenic properties for certain animals. Accordingly we timl that the literature devoted to the consideration of this species is very exteusive: but one may perhaps especially mention the investigations of Grawitz ( $\left.{ }^{7}\right)$, of Klemperer $\left({ }^{8}\right)$, and of Roux and Linnsisier $\left({ }^{9}\right)$. The papers by the last two authors give the results of a most careful research into the conditions under which the morphology of the fungus varies, together with a full historical account of the results of other workers down to 1890 . The authorities just quoted, and others also, have shown that in raluhits a general infection follows inoculation with cultures of this parasite derived from the human throat. Tessier $\left({ }^{10}\right)$, who has recently repeated these inoculation experiments, found that in guinea-pigs which died within from four to six days after the injection of a pure culture of $S$. allicans into the pleural sac, the presence of the parasite could he demonstrated in blood taken from the heart, the liver, and the spleen, bnth by microscopic examination and by culture methoris. With rabbits an intravenous injection was followed ly death within from four to six days, and the pamsite was recovered from lesions in the kidneys, the liver, and the spleen. Rabbits inoculated with the "yeast" form of the fungus, from cultures on acid media, died more rapilly and with more pronounced lesions than those which had received an injection of the filmmentous or mycelial form grown on alkaline mellia. In either case the form of parasite which was found in the lesions corresponds with the mycelial variety. Tessier also found that the injection of a culture into the subcutaneous tissue of either rabbits or guinea-pigs produced only a local lesion without 
general infection. A sero-purulent peritonitis, and a pleuritis with the formation of thick filsrinous filse membranes, resulted from injection into the respective sacs.

The piart played by st albicans in human pathology has not, however, up to the present time, appeared to be a particularly important one. In addition to its occurrence in the "thrush" of infants, and in the aphthous patches in the mouth, which are seen in adults during the comrse of enteric ferer and other prolonged illnesses, the presence of the parasite has been observed on the mucous membrane of the intestines. Thus, Payne $\left({ }^{11}\right)$ mentions the case of an infint who died of atrophy, in whom a great part of the ileum was covered by a growth of the parasite, which, however, avoiled the surface over l'eyer's patches. Payne also quotes a case of F. Wagner's in which the blood hecame infectel, and embolism of the brain resulted. And Tessier refers to another case, recorded by Schmorl, in which a general infection incurred. Artiult $\left({ }^{12}\right)$ found the parasite three times in the contents of the cavities in tubercular lungs, and records a case of pulmonary disease, which he believes to have been due solely to the presence of $s$ allicans. In 1893 Grasset $\left({ }^{13}\right)$ isolated from the pus of a small abscess of the gum, a micro-organism, which was apparently identical, morphologically, with $S$. albicans, but difiered from it in pathogenic action. It appeared to be essentially a lyogenic parasite, producing in rabbits and guinea-pigs either a listinct abscess or, mure rarely, a fluctuating swelling, which became ibsorbed and lisappeared. A general infection never resulted. In the same year Troisier and Achalme $\left({ }^{14}\right)$ described a yeast which they had isolated from the throat of a patient who was suffering from enteric fever, and in whom during the third week a white membrane develoyed orer the surface of the soft palate, tonsils, fances, and pharynx. Implanted on agar and incubated at $35^{\circ} \mathrm{C}$, the culture formed in two days, "une couche épaisse et bombée en son centre, cohérente, el'un gris rosé." On peptronised alkaline gelatine the growth was very slow, and numerous ascopores were met with. On slightly acid, wort development was very abundant, and long cells containing ascopores were again seen.

In addition to these last isolated instances of yeasts pathogenic for man, recorled up to the end of the year 1893, Bizzozero and others had described blastomycetes as occurring in connection with certain unhealthy conditions of the skin. Bizzozero mentioned particularly two different species thus met with, S. oralis and S. sphericus. Payne also speaks of $s$ capilliti, which he had met with in the scurf of the scalp in cases of pityriasis. But with regard to these skin-infecting yeasts, there was no evilence that they had any relation as causative agents to the cliseased condition present.

The first instance in which a genuine blastomycetic infection in man was subjected to careful investigation, was that recorded by 
Gilchrist (15), who in June 1394 showerl, betore the American Dermatological Society, some specimens from a case which had been treated as one of chronic scrofuloderma. In sections through the epidermis and corium certain bodies were seen, concerning which Gilchrist expressed the opinion that they would "in all prohability be found to belong to plant rather than to amimal life." And, after subsequent study, the conclusion wats arrived at, that the borlies in question were blastomycetes. They were found as buhling organisms in small well-defined miliary abscesses, in the rete mucosum and in the corium. The following facts were noted concerning them--(1) the organisms, wherever they appeared, were surrounded by inflammatory material; (2) their reproluction was carried on by gemmation : (3) they were never found intracellular (that is, with reference to epithelial cells); (4) they showed, in the arlut form, (ertain characteristics-a well-defined nucleus, a clear space letween the latter and the protoplasm, and a well-marked vacuole; (5) treatment with a caustic potash solution, showed that they were resistent bodies with a double contour. Two varieties of gimt cells wore described as occurring in the sections. "The one a curions form of siant cell, of which quite a number were seen. . . . In this specimen mly the nuclens of a hudling organism is seen. No vacule aum no clear space next to the capsule appear, but the contents apyeared just a shade lighter than the cell itself." In the other variety of giant cell, luduling organisms were to lee seen, which showed the structure, already described, of capsule, clear space, and vacule. Neither subcultures on artificial media nor experimental inoculation on animals were carried out.

Closely following on Gilchrist's first demonstration of his case was the publication of Busse's first paper in August $1894\left({ }^{16}\right)$. The paper dealt with the case of a woman who came under treatment in October 1893. In this patient, shortly after confinement, a swelling appleared over the tibia. In comection with this swellingr an alscess ultimately formed, and was opened in Tune 1894. From the pus of the abscess a reast was isolated by culture methols, and its pathogenicity tested on animals. The case afterwards came to a fatal issue; the operation wound over the tibia did not heal up; abscesses appeared elsewhere, over the una, on the forehead, and over the ribs: the patient died in November 1894. At the necropsy, in addition to the changes olserved duming life, lesions containing ycast cells were foumd in the spleen, in both kidneys, and in the lungs. In the left axillit there was a large soft swelling, and in the anex of the left lung there was a firm nolule, about the size of a hen's egrs, which was divicled by calcified trabeculae into chambers containing a sliny fluid. In the walls of the cavity remaining in the bone after the operation on the tibia, and also in some of the visceral lesions, a number of giant cells containing yeasts were seen. Busse prints out clearly the definite points of difference between the lesions met with in this case 
and chronic inflammatory changes on the one hand, and giant-celled sarcoma on the other. The yeast isolated showerl the following characteristics. It grew well on all the ordinary laboratory media. On solid media it grew in glistening white, quite round, raised colonies, which were at first isolated and then confluent. In streak culture a continnous narrow line of growth formed. No liquefaction of gelatine oceured. Toung colonies were danp and moist-looking. Cultures on potato at first white became, after a time, of a dirty brownish-grey colour. In broth the growth appeared first as a slimy white deposit. Crowth on artificial media uecurred at as low a temperature as $6^{\circ} \mathrm{C}:$; whilst at $40^{\circ} \mathrm{C}$. abortive forns were found, the yeast sometimes growing ont in short filaments. In the human subject the yeast occurred both within cells and lying free between the tissue elements. The yeast cells as they occurred in the tissues had a distinct capsule, which was not seen, as a rule, in cultures on artificial media. A capsule, however, conld be demonstrated in cultures grown on sugar-containing acid media.

The next case in which a blastomycetic infection in man was substantiated was that recorded by ('urtis of Lille $\left({ }^{17}\right)$. The patient was a healthy-Iooking young man, who came under treatment for a soft, semi-fluctuating tmmour of the right thigh, situated in Scarpa's triangle, together with a large lumbar abscess on the same sicle. The lesions became evident to the patient hinself in May, and were submitted to surgical treatment in July 1895. When incised the tumour of the thigh appeared to consist of soft gelatinous tissue, resembling that of a sareoma which had undergone a myxomatous degrenerition. From both lesions a yeast (S. subutaneus tumefaciens, Curtis) was isolated. An operation for the removal of the disease appeared to have been altogether successful, but the patient died ten months afterwards with meningeal symptoms of an obscure nature. In a further paper on the same case Curtis states the following conclusions, arrived at with regard to this yeast:-

1. That it is analogous in its nature to those yeasts described by Busse and Sanfelice, but to be distinguished from them by wellmarked differences.

2. That it grows best on acil and neutral media, and that its bio-chenical properties include the comversion of saccharose into invert sugatr and the production of ethyl aleohol and acetic acid. That it ferments shoose, lut not lactose or maltose.

3. That in the hmman subject it prohnces subcutaneous tumours, which macroseopically resemble softening myxosareomata, and which ultimately may hreak down and suppurate.

4. That it is pathorenic for the rat, the mouse, the dogr, and the rabbit, producing in the two first named subcutaneous swellings, resembling those found in the case of man.

Gilchrist and Stokes (18) have ${ }^{18}$ blished an acomut of a case of 
skin disease, characterised by chronic ulcerations in various parts of the body, which appeared to be caused by a blastomyces. The case, described as one of pseudo-lupus vulgaris occurred in a man at. 33, and the disease had been in existence for eleven years when the patient first came under observation. Yeast cells were identified microscopically in sections made through the epidermis and corium, and were isolated by culture methods. The parasite, $B$. dermatitidis (Gilchrist), varied from 10 to $20 \mu$ in diameter, and when growing on artificial media developed mycelial forms. These mycelial forms were not observed in the tissues, where the parasite was occasionally found enclosed within giant cells, but more commonly lying free between the tissue cells. On glycerine-agar and potato good cultures of the yeast were obtained; its growth was, however, rather slow, only becoming obvious after seven days. Growth was also obtained on most of the ordinary laboratory media. No fermentation occurred in glucose, lactose, or saccharose bouillons. Inoculation experiments carried out on mice and a pig gave negative results. In the dog, the horse, and the guinea-pig a general infection followed inoculation; nodules, containing yeast cells, being found in various internal organs. These four cases recorded by Gilchrist, Busse, Curtis, and Gilchrist and Stokes, appear to be the only instances in which an infection of man by a blastomyces, other than $S$. albicans, has been thoroughly worked out and well authenticated. There is too much uncertainty as to the significance of the alleged yeasts found in malignant new growths by those industrious workers Sanfelice and Roncali to allow one at present to accept the views founded on their observations. And one may say this without in any way disparaging the valuable work on the pathogenic action of yeasts carried out especially by Sanfelice, and without being forgetful of the debt which those of us who have paid special attention to this branch of pathology owe to him as a pioneer.

A few other isolated observations have been made as to the existence of blastomycetes in other pathological conditions in man. Thus Colpe isolated a yeast which he considered as the causative agent in a case of chronic cervical endometritis. De Simoni ( ${ }^{19}$ ) found, by staining methods, numbers of blastomycetes in twenty chronically enlarged tonsils which had been removed from twelve patients. The yeasts in question were sometimes intracellular, but more often lay free between the tissue cells. Some four years ago a case came under my notice, which is of some interest in connection with the subject of yeast infection. The patient was a man who for some years had suffered from albuminuria, for which there was no obvious cause. I examined two different samples of his urine, which had been drawn off by means of sterilised catheters. The amount of albumin present was considerable, but after a very careful microscopic examination no evidence, such as renal casts, red blood cells, leucocytes, or the like 
cruld be obtimed as to the cause of the tromble. Both samples of urine, however, collected with an interval of some days between, containeci a large number of yeast cells. The conditions under which the samples were collected and examined would appear to lave excluded the possibility of these yeasts having ohtained access to the urine after it was jassed; one was therefore compelled to assume that the yeast. cells were actually in the urine, as it was drawn off from the bladder. What the pathological condition underlying their presence might have been I am quite unable to suggest. The case is, however, just worth mentioning, as I have since found that an appearance of yeast cells in the urine is an occisional result of the experimental infection of animals with yeasts.

\section{Spoxtaneous Blastonychic Ixfection in Aximals lower thas Max.}

Maffuce and Sirleo $\left({ }^{20}\right)$ have described two cases of spontaneous yeast infection in guinea-pligs; in one case the disease occurred in the lungs, in the other in comection with the intestine.

Tokishige ("1) has described a blastomycetic disease in horses and cattle which occurs in Japan. The disease is charicterised ly the formation of granulomata, which occur in the sulcutaneous tissue in the lungs, in the testicles, and in other organs. In the nodules thus formed a yeast, S. farciminosus (Tokishige) was identified, and from them it was obtalined in pure culture. This yeast is characteriserl by an extremely slow rate of growth, no development heing obvious in peptone beef-broth until the end of seventeen days, on nutrient agar until the end of thirty days, whilst growth on nutrient gelatine was still slower. On artificial media i marked development of "hyphe" forms was observel. Inoculation experiments on horses, guinea-pigs, rabbits, dogs, cats, swine, and calves gave negative results, so far as any general infection was concerned. In the horse only a localised abscess followed the subcutaneous injection of a culture, and in the thin pus which resulted characteristic yeast cells could he seen. I have elsewhere $\left({ }^{22}\right)$ recorded a case of what appeared to be a similar disense occurring in a cow in this country. Fermi and Aruch $\left({ }^{23}\right)$ believe that Cryptococcus farciminosus, which Rivolta deseriled as the cause of lymphangitis cpizootica in horses, a disease which bears some general resemblance to the condition described by Tokishige, is in reality a blastomyces.

Sanfelice (24) has isolated from the calcitied glands of an ox a yeast, $S$ litogenes, which is pathogenic for white rats, rablits, and sheep.

\section{Expermextal Ixocllations ox the Lower Animals.}

The publication of the papers of Gilchrist, Busse, and Curtis naturally acted as a stimulus to the experimental investigation of the 
Jathogenic properties of various yeasts, when inoculated into the lower animals. And out of the bulk of the work in this direction, which has heen carried out during the last four years, that of sinfelice and of Maffucei and Sirleo has heen particularly valuahle. Justice cannot he done to the investigations of these workers in the space here available, and since the results of their work is easily accessible to those interested in the subject it will be umecessary to further refer to it now.

Lydia Rabinowitsch (25) has carefully carried out a long series of experiments on the lower animals, using for the purlose some fifty different species of yeasts, derivel from various sources. Of these the following were found to le gathogenic for animals:-

1. Monillia randida-pathogenic for mice and rablits, not for guinea-pigs.

2. A wild yeast, obtained from fermenting tigs - pathogenic for mice; large doses injected into the peritoneum of guinea-pigs produced only a slight rise of temperature.

:3. A distillery yeast-pathogenic for mice.

4. A baker's yeast-pathogenic for mice: this yeast showed a formation of mycelium.

5. A will yeast, from wine grape-pathogenic for mice; this yeast formed long sprouting hands, but no actual nycelium was seen.

6. A yeast isolatel from malt mash; this yeast was pathogenic for mice, and its pathogenicity seemed to be considerably exalted after repeated fassages through experimental animals; experinents on guinca-pigs and rabbits gave negative results.

7. Delbriek (Lindner)--pathogenic for mice anl rablits not for grinea-pigs.

labinowitsch comes to the conclusion that these jathogenic yeasts act by blool infection rather than by nere intoxication; she found no geast that was pathogenic for grinea-pigs, nor was any case of tumour formation olserverl. Gran's method of staining was found useful for clistinguishing the yeast cells in the tissues, in which, in the case of mice and sometimes in rabbits, they appeared to be wirlely distrihuterl.

Gilkinet $\left({ }^{26}\right)$ carried out a number of experiments to ascertain the fate of serevisice when introduced into the living holy, and amongst them were the following. Three rabbits were injected with pure cultures of the yeast. Each received 1 e.c. of an emulsion into an aural vein, and the animals were killed at the end of six, twenty-four, and seventy-two hours respectively. Yeast cells were recovered by culture methods from the liver, lung, and spleen of the first rabbit, but could be recognised neither microseopically nor by culture. methods in the bodies of the other two. In none of the cases was the yeast found in the urine. In a second series of experiments, capillary tubes, closed at one end and containing yeast emulsion, were introduced into the peritoneal cavity of rabluits. 
The animals were killed at the end of four, nine, aud twelve days respectively. At the end of four days the tubes contained unaltered yeast cells, hut no lencocytes. At the end of nine and twelve days the tubes still contained a few unaltered yeast cells, but the majority of these cell forms were in a state of degeneration. In these cases, as in the first, no leucocytes were to be seen in the tubes. None of the three sets of tuives gave any growth on artificial media after removal from the peritoneal cavity. Gilkinet comes to these conclusions(1) that $S$. crerisice, injected into a vein or into the subcutaneous tissue of rabbits, produces no morbil symptoms, either local or general; (2) that S. cerevisia, does not multiply in the tissues, but is destroyed by the tissue juices, the lencocytes taking no part in the matter; (3) that the "pathogenic yeasts" belong to species altogether different from sererisice. Gilkinet concludes his paper by quoting the recent work of Jona $\left({ }^{27}\right)$ as agreeing in the main with his own.

\section{Experimextal Iroculations With vaRious Yeasts.}

My own experimental work with regarl to the pathogenic action of yeast; was undertaken with a view of testing the virulence of some of the commoner yeasts, and of stulying the nature of the tumours, if any, produced by them. In the first series of experiments the following yeasts in pure culture were used:- $S$. cercisicic, $S$ pastorianus 1, 2, and 3, s. cllipsoidens, st. allues, s. albus liquefaciens, $S$. anomalus, $S$. albicans, and a red yeast isolated from some fitces in a case of enteric fever. In the second series of experiments I used a hitherto undescribel yeast, which was isolated from the mucus of the throat in several cases of pharyngitis.

\section{SERIES I.}

In all these experiments the inoculated material consisted of an emulsion, mate by shaking up with 3 c.c. of sterile normal saline solution a forty-eight hours' old culture, at 22 c.c., of the particular yeast in a sloped glucose agar tube. In every case the close used for inoculation was 1 c.c. for a rabbit, and 0.5 c.c. for a guinea-pig. Glucose agar tujes were used for all subcultures from the tissues.

\section{S. reverisia-}

RABBIT 1 was inoculaterl in the subcutaneous tissue of the lumbar region, and clied on the tenth diy. There was at tumour ahout the size of a horse bean at the site of inoculation. The tumun was of softish consistence and of a yellowishliwhe colour. A jure culture of the yeast was obtained from the tumour, whilst tubes inoculated from urine, which wis in the bladder at the time of ileath, remained sterile. Yeast cells were identified in great abundance in the cumour in the fresh state, and in nuch smaller numbers in hardened and stainerl sections.

RABBIT 2 was similarly inoculated with a culture obtained from another source. This animal died on the fifth day. At the site of inoculation there 
was a mass of soft white material, somewhat smaller than that found in Rahbit 1, and from this a mure culture of the yeast was obtained as before. Numerous yeast cells could be identified in the fresh tumour on microscopi: examination. Tubes inoculated from the heart blood and urine remained sterile.

Gutises-pig 1 was inorulated in the subeutaneons tiswe with the sime emulsion as that used for habbit 1 . The animal died within forty-eight hours. After death no trare of the inoculation was found, except a little capillary injection on the unler surface of the skin at the point operated on. Tubes inoculated from various organs and from the heart blool remained sterile.

\section{S. allees---}

RaBBiT 3.- Inoculated in subentaneous tissue of lumbar regrion; died on the nineteenth day. There was a white flattened tmmour at the site of inoculation mensuring about $3 \mathrm{cms}$. by $2 \mathrm{cms}$. in superficial extent, and about 5 cms. in thickness. Only a very few yeast cells were identified on micruscopic examination of hardened sections. This rabbit wis a rather small, whitehaired animal, and on the fifteenth day its fur began to fall off rapilly, so that when it died it was almost devoid of hair.

(iviNeA-PIi 2 was inoculated in subcutaneous tissue of lumbar region; no obvious result: followed, and on examination of the body, six weeks later, no pathologieal changes were fouml.

Gunverplg 3 was inoculated in subcutaneous tissue. The animal died iwenty-four days after, but no pathological changes were found except a few white streaks in the liver. Culture tules from various organs remained sterile.

WhTr: Rat 1 received 0.25 ce. of the emulsion in the subcutineous tissue of the back. The animal died on the seventh day. Culture tubes from various organs remained sterile. No pathological changes were noticed in the horly, ant the canse of death was not obvious.

\section{S. allues liquefacious--}

RanBrT 4.- Inoculated in the subentaneous tissue of the bark; dierl on the eighteenth day with a tumour at the site of inoculation, closely resembling that f:nund in Rabbit 3. A number of nodules were found in the liver. Culture tubes, inoculated from the tumour and from a liver nodule, gave a growth of the yeast; tubes inoculated from the heart blood remained sterile. Fumerous yeast cells conld be identified in the tumour on microscopic examination. This rabbit was a long-hairel white one, and it also, like Rabhit 3, lost nearly all its fur shortly before death.

(reINEA-pig 4.-Inoculated in subeutaneous tissue of hack. An abscess formed which broke and healed up. Animal survived, showing no other symptoms.

White nat 2.-Innculated in subcutaneous tissue of back; died on seventh day. The only pathological change found in the body, except some white streaks in the liver, wiss a smill cyst lying between the stomach and the peritoneum covering that viscus at its lower border. This cyst was full of a grumous sticky fluid, in which a number of yeast cells, many in the act of budling, were easily ilentitiml. So cultures were made.

\section{S. cllipsoideus-}

RaBmir 5.-Inoculated in subcutaneous tissue of back; died on twenty. thirl day with a small white tumour, rather larger than a pea, at the site of iroculation. Culture tubes from tumour and various organs remained sterile.

RABBI' 6. - Inoculated in subcutimeous tissue of back; died on the sixth day. There was an oval softish tumonr, the size of a small bean, at the site of inoculation. The under surface of the skin and the subcutaneous tissues in the 
neighbourhood of the tumour were intensely congested. The mesenteric glands were decidedly enlarged. There had been a considerable amount of hæmorrhage into the larger bowel; the urine in the bladder was mixed with blood. Microscopic examination of the tumour showed the presence of a large number of yeast cells. Pure cultures of the yeast were obtained from both the tumour and from a mesenteric gland, the heart blood was sterile, a bacillus grew on the tubes inoculated from the kidney.

\section{S. pastorianus 1-}

$R_{A B D I T} 7$.- Inoculated in subcutaneous tissue of lumbar region; died on the twenty-fifth day. There was a fiattened white tumour, measuring $2 \mathrm{cms}$. by $2.5 \mathrm{cms}$. at the site of inoculation. Some small whitish nodules were also seen in the lungs. No cultures made.

\section{S. pastorianus 2--}

RABBIT 8.--Inoculated in lumbar region; died on the seventh day after considerable wasting. There was nothing to be seen at the site of inoculation; there were a number of small whitish nodules in the lungs (not examined microscopically), as in Rabbit 7 . Culture tubes inoculated from lungs and other organs remained sterile.

GuINEA-PIG 5.-Inoculated in muscle of thigh; died on eighth day. No obvious cause of death, nor was any pathological change except a small necrotic patch in the liver observed. No cultures were attempted from this animal.

\section{T. S. pastorianus 3}

$R_{\text {ABBit }}$ 9.- - Inoculated in subcutaneous tissue of lumbar region; died on twenty-second day. No pathological changes were observed, and no obvious canse for death.

GuINEA-PIG 6.--Inoculated in muscle of thigh; died on the thirty-second day. The only pathological changes observed were a few small white streaks in the liver.

\section{S. anomalus-}

$R_{A B B I T} 10$.- Inoculated as others; died on thirty-first day with extensive coccidiosis. At the site of inoculation there was a little thickening of the skin with some injection of the cutaneous blood vessels; no other pathological changes, which could be attributed to the inoculation, were observed.

\section{S. albicans-}

RABBIT 11.-Inoculated in subcutaneous tissue of back; died on twentyninth day with a large flattened tumour at the site of inoculation. Examination of the fresh tumour showed the presence of a large number of yeast cells, both contained within the tissue cells and lying between then. No mycelial forms were met with. Culture tubes inoculated from the tumour gave a free growth of $S$. albicans; tubes inoculated from the urine remained sterile.

\section{A red yeast which was isolated from the faces of a case of enteric fever-}

RABBIT 12 was inoculated in the subcutaneous tissue of the back; Guinea-pig 7 in the subcutaneous tissue of the abdomen; and GuineaPIG 8 in the muscle of the thigh. A white mouse received 0.1 c.c. of the emulsion under the skin of the back. No obvious effect followed the inoculation in any of these cases, all the animals surviving. 
The results of these few experiments may be tabulated as below :-

TABLE OF EXPERIMENTS.

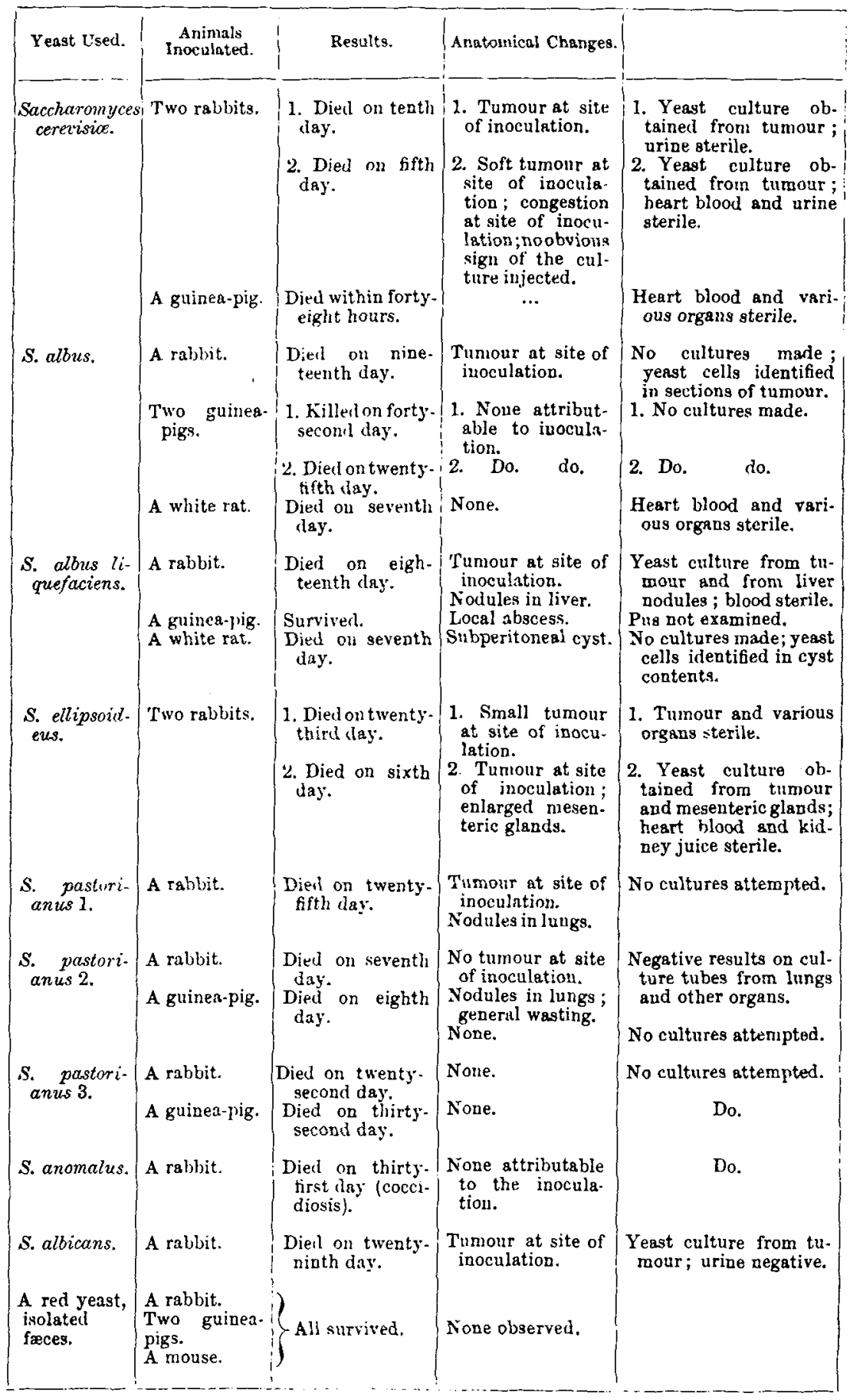




\section{SERIES II.}

The preceding general experiments having been rarried out with the varions reasts mentioned, a second series was commenced, with the view of studying in further detail the action of a pathogenic yeast on the living tissues.

The species selected for this purpose was one which was isolated from two cases of pharyngitis, in one of which it was assor.iated with the Klebs-Libller bacillus of diphtheria. As to the clinical import of this particular speries in these two cases, I hare now mothing to saly,- whether it wecurred as the cause of the pharyngitis, or whether it was present in the pharyngeal secretion merely as a casual parasite. I fomd, however, that it had a decided pathogenic action on the rablit, and hence its use for the present purpose. This yeast does not correspond in its characters with any of the species bitherto described as accurring in the mouth or throat, and I propose to give it the name of Srecharomyees temefacions allus.

The general appearance of the yeast is well shown in I'late IV. Fig. 1, which is notahle as the reproduction of a photugraph of a yeast in the living state. For this photograph, which is, I moderstand, as such unique, as well as for the others illustrating this paper, I am indelited to the skill of Mr. J. Barnard, to whom I may here express my thanks for the trouble which he has taken in the matter. An averagesized cell from a forty-eight hours' old culture of this yeast measures from 3 to $4 \mu$ in diameter. On artificial media of varions binds the rells have always appeared in "yeast" form, and have never under these conditions shown any tendency to "mycelial" formation. In the cells a central vacuole is often seen, its develojment dejending on the age of the cell, as evidenced hy the size of the latter. Every yeast cell shows at least one highly refractile nuclens, some show two. The nuelei in a living culture, suspended in nomal saline solution, show distinct "to and fro" movenent; when a valuole is present the nucleus appears to move round its edge in the surromding protoplasm of the cell. Spore formation was not observed on any of the culture media used, reproduction taking place exclusively by " hudling."

The cultures ferment shoose energetically, maltose onsiderably less rapidly, and have no action of the sort unn lactose.

The yeast grows well on all the ordinary labmatry media, yielling a rather more rapidly growing and more profuse growth at $37^{\circ} \mathrm{C}$. than it does at $22^{\circ} \mathrm{C}$. On nutrient agar, or on nutrient glucose agar, a free growth occurs within twenty-four hours at the higher temperature, the yeast grirhally covering the surface of the medium as a thick, heary-lowking, moist white layer. In peptone beef-hroth the growth is rather scanty, and the yeast collects at the hottom of the tube, leaving the upper part of the fiuid quite clear; no growth on the surface ever wcurs. In alkaline litmus milk good growth occurs, 
without causing any curdling or obvious alteration in the medium. Equally good growth took place on either nentralised or naturally acid nutrient gelatine, and no liquefaction occurred during twenty days' growth. The growth on gelatine has a shiny appearance, aud is quite white. On potato the growth is dry looking, and at first white, but after a time the cultures assume a hrownish tinge. On horses' blood serum growth is scanty, the result appearing as a dry-looking, thin white patch. In its staining reactions this yeast fresents nothing particular when taken direct from artificial media. It stains well by Gram's method. Very young cells stain in a uniform manner with Löffler's methylene-hlue solution; older cells, however, do not stain evenly, but show in their substance larger or smaller patches which assume a redilish tinge, in contrast to the remainder, which is of a pure blue. On staining with carbol-fuchsin for thirty seconds the patches which stain red with Lüftler's blue take the colour intensely, and show a deep red staining; the rest of the cell stains a faint pink colour. With Bismarck-brown solutions, the patches or particles take the stain more deeply than the rest. With methyl-violet again, the patches or particles have a greater affinity for the stain than the rest of the cell.

The above remarks apply to cultures forty-eight hours old, grown on nutrient glucose agar at a temperature of $37^{\circ} \mathrm{C}$, the specimens jeing fixed in the usual way. It was not quite clear what the relations of these "patches" were to the "vacuole" appearance seen in the living cell. A very common arrangement in the stained specimen was one largish and almost circular patch, and one, two, or three smaller points which stained in the manner indicated. With Ehrlich's hematoxylin solution the cells stain in a fairly uniform manner. Fat formation within the cells occurs early when the yeast is growing on nutrient slucose agar. A preparation from such a culture of twentyfour hours' growth shows a few cells which will react when treated with a 1 per cent. solution of osmic acid. The same culture at the end of seventy-two hours will contain a considerable uunlser of cells which, when treated with the reageut, show a good proportion of fatty matter within their substance. The fatty natter occupies the central portion of the cell, and the peripheral portions do not appear to contain any.

The presence of glycogen within the cells was easily demonstrated by treatment of a preparation from a ten days' old culture on nutrient glucose agar with weak iodine solution. A certain proportion of the cells showed a distinct reddish-brown coloration, indicating the presence of glycogen.

The life of individual cultures on nutrient glucose agar was not exactly determinerl; but subcultures from tubes five months old grew in the normal manner, and exhibited the normal virulence for rabbits. 
The virulence of the yeast for rabbits appeared to remain unaltered after fifteen months, the original culture having meanwhile been passed through varions animals. The pathogenic action of this yeast was tested on rabbits, guinea-pigs, tame rats, and tame mice. The following Table gives an abstract of the results obtained by inoculation, the method of procedure being the same as in Series I:-

TABLE OF EXPERIMENTS-SERIES II.

\begin{tabular}{|c|c|c|c|c|}
\hline Animal. & $\begin{array}{l}\text { Dase of } \\
\text { Enulsion. }\end{array}$ & Result. & Anatomical Changes. & $\begin{array}{l}\text { Result of Inoculating } \\
\text { Culture Tubes. }\end{array}$ \\
\hline RABด:T & & & & $\cdots \cdots$ \\
\hline 1 & 1 c.t. snbcut. & $\begin{array}{l}\text { Died on ninth } \\
\text { day. }\end{array}$ & $\begin{array}{l}\text { Tumour at site of in. } \\
\text { oculation. }\end{array}$ & $\begin{array}{l}\text { Heart blood, nega- } \\
\text { tive. }\end{array}$ \\
\hline 2 & , & $\begin{array}{l}\text { Vied os rinth } \\
\text { day. }\end{array}$ & $\begin{array}{l}\text { Tumour at site of in- } \\
\text { oculation; nodules in } \\
\text { liver gnd kidneys. }\end{array}$ & $\begin{array}{l}\text { Tumour and kid- } \\
\text { ney, growth. }\end{array}$ \\
\hline 3 & ", & $\begin{array}{l}\text { Died on seventh } \\
\text { day. }\end{array}$ & $\begin{array}{l}\text { Tumour at site of in - } \\
\text { oculation. }\end{array}$ & $\begin{array}{l}\text { Tumourgave growth; } \\
\text { kidneys and urine, } \\
\text { negative. }\end{array}$ \\
\hline 4 & ", & $\begin{array}{l}\text { Died on fourth } \\
\text { lsy. }\end{array}$ & $\begin{array}{l}\text { Very small mass of } \\
\text { solish wbite moter- } \\
\text { ial at site of inocula- } \\
\text { tion. Both kidoeys } \\
\text { studded with small } \\
\text { nolules on surface } \\
\text { and in cortex. }\end{array}$ & $\begin{array}{l}\text { Tunour and kid- } \\
\text { neys, growth. }\end{array}$ \\
\hline 5 & ", & $\begin{array}{l}\text { Died on eighth } \\
\text { day. }\end{array}$ & $\begin{array}{l}\text { Tumour at site of in- } \\
\text { oculation ; numerous } \\
\text { nodules in lungs, } \\
\text { liver, kidneys, and } \\
\text { scattered over dia- } \\
\text { flragrn. (See Plate } \\
\text { IV. Figs. } 3,4,5,6 .)\end{array}$ & $\begin{array}{l}\text { Tumour and nodules } \\
\text { in kidneys, liver, } \\
\text { and diaghragn, } \\
\text { also urine, all posi- } \\
\text { tive (See Plate } \\
\text { IV. Figs. 1, 7, and } \\
\text { 8.) }\end{array}$ \\
\hline 6 & ," & $\begin{array}{l}\text { Died on fiftieth } \\
\text { day. }\end{array}$ & $\begin{array}{l}\text { Large soft tumour at } \\
\text { site of inoculation } \\
\text { (partly destroyed } \\
\text { after death by rats). }\end{array}$ & No tubes inoculated. \\
\hline 7 & $\begin{array}{l}1 \text { c.c. into } \\
\text { post-femorial } \\
\text { muscles. }\end{array}$ & Survived. & $\begin{array}{l}\text { Small swelling de- } \\
\text { veloped at site of in- } \\
\text { oculation, but subse- } \\
\text { guently disappeared } \\
\text { spontaneons?y. }\end{array}$ & .. \\
\hline 8 & $\begin{array}{l}2 \text { c.c. into Jum- } \\
\text { bar muscles. }\end{array}$ & $\begin{array}{l}\text { Died on eleventh } \\
\text { day. }\end{array}$ & 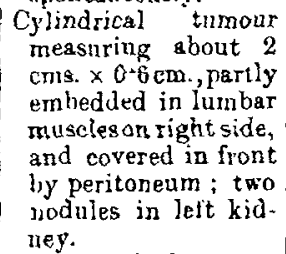 & $\begin{array}{l}\text { Tumourgavegrowth; } \\
\text { heart blood and } \\
\text { uripe, negative. }\end{array}$ \\
\hline 9 & $\begin{array}{l}1 \text { e.e. into } \\
\text { post-femoral } \\
\text { muscles. }\end{array}$ & $\begin{array}{l}\text { Died after forty } \\
\text { three hours. }\end{array}$ & $\begin{array}{l}\text { Niss of softish mater- } \\
\text { ial at site of inocula- } \\
\text { tion; both luugs } \\
\text { showed a number of } \\
\text { small hæmorrhagic } \\
\text { puncta. }\end{array}$ & $\begin{array}{l}\text { Site of inoculation } \\
\text { and urine gave } \\
\text { grow th; he } b \mathrm{rt} \\
\text { blood, negative. }\end{array}$ \\
\hline 10 & $\begin{array}{l}\text { a c.c. into } \\
\text { post-femoral } \\
\text { inuscles. }\end{array}$ & $\begin{array}{l}\text { Died sfterninety- } \\
\text { four hours. }\end{array}$ & $\begin{array}{l}\text { pluncta. } \\
\text { Flattened mass of } \\
\text { softish matrial at } \\
\text { site of inoculation. }\end{array}$ & $\begin{array}{l}\text { Site of inoculation } \\
\text { gave growth; heart } \\
\text { blood and urine, } \\
\text { negative. }\end{array}$ \\
\hline
\end{tabular}


Table of Experiments, Series II.-continued.

\begin{tabular}{|c|c|c|c|c|}
\hline Animal. & $\begin{array}{l}\text { Dose of } \\
\text { Emulsion. }\end{array}$ & Result. & Anatonical Changes. & $\begin{array}{l}\text { Result of Inoculating } \\
\text { Culture Tubes. }\end{array}$ \\
\hline $\begin{array}{l}\text { RABBIT } \\
\quad 11\end{array}$ & $\begin{array}{l}1 \text { c.c. into pop- } \\
\text { liteal space. }\end{array}$ & $\begin{array}{l}\text { Died on foul- } \\
\text { teenth day. }\end{array}$ & $\begin{array}{l}\text { Firm lobulated tum- } \\
\text { our, partly project- } \\
\text { ing into popliteal } \\
\text { space, partly em- } \\
\text { bedded in posterior } \\
\text { tibial muscles. (See } \\
\text { Plate IV. Fig. 2.) }\end{array}$ & $\begin{array}{l}\text { Tumourgave growth: } \\
\text { heart blood and } \\
\text { urine, negative. }\end{array}$ \\
\hline 12 & $\begin{array}{l}1 \text { c.c. into } \\
\text { post-femoral } \\
\text { muscles. }\end{array}$ & $\begin{array}{l}\text { Died on four- } \\
\text { teenth day. }\end{array}$ & $\begin{array}{l}\text { Largish tumour at site } \\
\text { of inoculation. }\end{array}$ & $\begin{array}{l}\text { Tumourgave growth; } \\
\text { heart blood, nega- } \\
\text { tive. }\end{array}$ \\
\hline 13 & $\begin{array}{l}1 \text { c.c. in to peri- } \\
\text { toneal cavity. }\end{array}$ & Survived. & No obvious ill effects. & $\cdots$ \\
\hline 14 & $", \quad "$ & $\begin{array}{l}\text { Died twenty- } \\
\text { seventh day. }\end{array}$ & $\begin{array}{l}\text { No changes attribut- } \\
\text { able to yeast inocula- } \\
\text { tion ; probable canse } \\
\text { of death, coccidiosis. }\end{array}$ & $\begin{array}{l}\text { Liver, kidneys, } \\
\text { urine, and heart } \\
\text { blood, negative. }\end{array}$ \\
\hline$\underset{\text { PIG }}{\text { Gunea- }}$ & & & & \\
\hline $\begin{array}{l}1 \\
2\end{array}$ & $\begin{array}{l}1 \text { c.c. subcut. } \\
1 \text { c.c. intra- } \\
\text { nutscular. }\end{array}$ & $\begin{array}{c}\text { Survived. } \\
\qquad,\end{array}$ & $\begin{array}{c}\text { No obvious ill effects. } \\
, ",\end{array}$ & $\begin{array}{l}\cdots \\
\cdots\end{array}$ \\
\hline $\begin{array}{l}3 \\
4 \\
5\end{array}$ & $\begin{array}{c}1 \text { c.c. subent. } \\
, ", ", \\
, ",\end{array}$ & $\begin{array}{l}\text { '", } \\
\text { Died" on twelfth } \\
\text { day. }\end{array}$ & $\begin{array}{l}\text { Small" softish "mass at } \\
\text { site of inoculation. }\end{array}$ & $\begin{array}{c}\ldots \\
\text { Site of inoculation, } \\
\text { positive; heart } \\
\text { blood, negative. }\end{array}$ \\
\hline 6 & $\begin{array}{c}0.5 \text { c.c. intra- } \\
\text { muscular. }\end{array}$ & $\begin{array}{l}\text { 1)ied on eighth } \\
\text { day. }\end{array}$ & $\begin{array}{l}\text { Flattened layer of soft } \\
\text { material at site of } \\
\text { inoculation. }\end{array}$ & $\begin{array}{l}\text { Site of inoculation, } \\
\text { positive; heart } \\
\text { blood, negative. }\end{array}$ \\
\hline $\begin{array}{l}\text { WHite } \\
\text { RAT }\end{array}$ & & & & \\
\hline $\begin{array}{l}1 \\
2\end{array}$ & $\mid \begin{array}{c}0.5 \text { c.c. subent. } \\
,, \quad,\end{array}$ & $\begin{array}{c}\text { Survived. } \\
\text { ", }\end{array}$ & $\begin{array}{c}\text { No obvious ill effects. } \\
\text { ", }\end{array}$ & \begin{tabular}{c}
\multicolumn{2}{c}{$\ldots$} \\
$\ldots$ \\
Numerous
\end{tabular} \\
\hline 3 & $\mid \begin{array}{c}0.2 \text { c.c. into } \\
\text { post-femoral } \\
\text { muscles. }\end{array}$ & $\begin{array}{l}\text { Died on twenty- } \\
\text { first day. }\end{array}$ & $\begin{array}{c}\text { Numerous caseous } \\
\text { nodules in lungs. }\end{array}$ & $\begin{array}{l}\text { tures from heart } \\
\text { blood, lungs, and } \\
\text { other organs in }\end{array}$ \\
\hline 4 & $\begin{array}{c}0 \cdot 2 \text { c.c. intolum- } \\
\text { bar muscles. }\end{array}$ & $\begin{array}{l}\text { Died in fifth } \\
\text { month. }\end{array}$ & ", & $\begin{array}{l}\text { white rats } 3,4 \text {, and } \\
5 ; \text { all gave nega- }\end{array}$ \\
\hline 5 & $\left|\begin{array}{c}0.2 \text { c.c. into } \\
\text { peritoneum. }\end{array}\right|$ & $\begin{array}{l}\text { Died in sixth } \\
\text { month. }\end{array}$ & ", & $\begin{array}{l}\text { tive results so far } \\
\text { ss yeasts are con- } \\
\text { cerned. }\end{array}$ \\
\hline $\begin{array}{l}\text { WHITE } \\
\text { Morst }\end{array}$ & & & & \\
\hline 1 & $\left\{\begin{array}{c}0.1 \text { c. c. into fem. } \\
\text { oral muscles. }\end{array}\right.$ & $\begin{array}{l}\text { Died forty-eight } \\
\text { hours. }\end{array}$ & $\begin{array}{l}\text { No obvious change } \\
\text { found post-mortem. }\end{array}$ & Heart blood, growth. \\
\hline 2 & , , , & $\begin{array}{l}\text { Died forty-three } \\
\text { hours. }\end{array}$ & ,, & $\begin{array}{l}\text { Heart blood and } \\
\text { liver, growth. }\end{array}$ \\
\hline 3 & 0.1 c.c. subeut. & $\begin{array}{l}\text { Died twenty-four } \\
\text { hours. }\end{array}$ & " & \\
\hline 4 & $"$ & $\begin{array}{l}\text { Died twenty } \\
\text { hours. }\end{array}$ & " & Heart blood, growth. \\
\hline
\end{tabular}

From the accompanying table it will be seen that six rabbits were inoculated in the subcutaneous tissue, and that all of these died. Six other rabbits received intramuscular injections; and of these five died. The one survivor developed a small swelling at the site of inoculation, which subsequently disappeared spontaneously. Two rabbits received 
an injection into the peritoneum, and of these one survived and the other died at the end of four weeks, apparently from causes quite independent of the inoculation. Of the twelve rabbits which received either a subcutaneous or an intramuscular injection, three (Rabbits, 4, $9,10)$ died within ninety-six hours; in each case a mass of semi-solid material was found at the site of inoculation, in which yeast cells were numerous, but which was otherwise sterile. Seven animals died between the seventh and fourteenth day after the inoculation, and one survived to the fiftieth. In all these last eight rabbits there was definite tumour formation at the site of inoculation, and in seven of them pure cultures of the yeast were obtained from the growth. In the remaining case no cultures were attempted, as the body of the animal was attacked by rats after death, and the tumour was partially eaten. The proportion of cases in which secondary deposits in internal organs were found will be seen on reference to the table of experiments. In every case the culture of yeast obtained from the primary tumour was absolutely pure, but in some of the tubes inoculated from secondary deposits in internal parts contaminating bacteria occurred side by side with the yeast culture. In no case was a culture of the yeast obtained from the heart blood, but cultures were obtained in two cases out of six in which urine found in the bladder after death was put on glucose agar tubes. The following will serve as examples of the morbid changes following the inoculation of rabbits with $S$. tumefaciens albus :-

RABBIx 5. - This animal received 1 c.c. of an emulsion into the subcutaneous tissue of the left side of the lumbar spine. Death occurred on the eighth day, and a largish flattened tumour measuring $2 \mathrm{cms}$. by $1.5 \mathrm{~cm}$. superficially, and about $0.4 \mathrm{~cm}$. in thickness was found at the site of inoculation. This tumour was definitely encapsuled and could be easily separated from the muscle below, but was slightly adherent at one spot to the skin above. The tumour was yellowish white in colour and mostly of firm consistence, but the more central portion of the mass consisted of softish, almost creany, material which contained an enormous number of yeast cells. The liver showed a number of small white nodules, some deeply embedded in its substance, others standing out somewhat from its surface. The surface of both kidneys was studiled over with white nodules, of which some were also found deep in the substance of the cortical portion. The mesenteric glands were markedly enlarged, and white. The spleen appeared to be normal. The diaphragm presented, scattered over it, a number of small nodules (Plate IV. Figs. 3,6) of less size than those found in the liver and kidney. A number of small white nodules could also be seen in the substance of the lungs. Tubes of glucose agar were inoculated from the primary tumour, from the nodules in the kidney, liver, and diaphragm, and also from the urine. All these tubes, except one inoculated from a nodule on the diaphragm, in which a contaminating bacillus was present as well as the yeast, in twenty-four hours showed a pure culture of the yeast. Tubes inoculated from the heart blood remained sterile. The primary tumour and the secondary nodules in the kidneys and on the diaphragm, examined microscopically, appeared to be granulomata, and contained numerous yeast cells (Plate IV. Figs. 4, 5). The primary tumour was surrounded by a definite capsule of fibrous tissue which was less marked or absent in the secondary nodules on the diaphragm. 
$R_{A B B I T} 8$.-This rabbit received what was intended to be a subcutaneous injection on the right side of the lumbar vertebræ; the post-mortem examination showed, however, that the injection had penetrated into the lumbar muscles. The animal died on the eleventh day, and in the subcutaneous tissue at the site of inoculation a small isolated nodule about as big as a pea was found. On opening the abdomen a long cylindrical tumour was found on the right side of the spine, projecting somewhat into the peritoneal cavity, partly embedded in the lumbar muscles, and covered in front by the parietal peritoneum. The tumour was a little over $2 \mathrm{cms}$. in length and $0.6 \mathrm{~cm}$. in diameter, the peritoneum was easily peeled off it in front, whilst the muscle substance in which it was embedded was separated from it with some little difficulty, fibres remaining adherent here and there to the surface. The kidney on the left side showed a large mass of white growth at its upper end, and a small nodule embedded in its substance. A pure culture of the yeast was obtained from the tumour at the side of the spine and from the larger nodule in the kidney; the heart blood and urine were sterile.

$R_{A B B I T} 11$. - This rabbit received 1 c.c. of the emulsion deeply into the popliteal space, and death occurred on the fourteenth day. A largish, frm, nodulated tumour was found at the site of inoculation. The upper part projected free in the loose cellular tissue at the back of the knee-joint; the lower part of the tumour was embedded in the muscles behind the tibia (Plate IV. Fig. 2). In this case, as in the last, the muscle fibre was in places closely adherent to the surface of the tumour. No other morbid changes were found in the body. A pure culture of the yeast was recoverel from the tumour; the heart blood was sterile.

In guinea-pigs the pathogenic action of the yeast was not constant in its effects. Six guinea-jigs in all were inoculated. The first two were operater on early in the course of the experiments, and both survived. The next four were inoculated about twelve months later, after the culture had passed through various rabbits. Two of these four survived without showing any morbid symptoms, and two died. Each of these last was found after death to have, at the site of inoculation in the subcutaneous tissue, a small collection of soft whitish material which could not, however, in either case, be said to constitute a definite tumour, such as those found in rabbits. A pure culture of the yeast was in each case recovered from this material. No other morbid changes were found, and tubes of glucose agar inoculated from the heart blood in one case, and from the heart blood, liver, and hilneys in the other, remained sterile.

The results of inoculation of this yeast in tame rats also left the question of its pathogenicity for these animals in a state of some doubt.

RATS 1 and 2 were inoculated from the same culture early in the course of the experiments, and both survived without suffering any obvious ill effects. Rats 3, 4, and 5 were also inoculated at the same time; each received a somewhat smaller dose than was used in the case of Rats 1 and 2, and the culture had been passed through several rabbits since the two latter animals were inoculated. The Rats 3,4 , and 5 died at intervals of three weeks, five months, and six months respectively after inoculation. In each case remarkable changes were found in the lungs after death. In the case of Rat 3 the whole of the anterior lobe of the left lung and the posterior lobe of the right lung presented externally the appearance of being infiltrated with large yellowish nodules. In sections it was seen that some of these nodules had broken down in the centre so as to enclose comparatively large cavities filled with a glairy, glutinous fluid, which in the cavities of the left lung was opaque and somewhat pus-like, and in the right lung was dark coloured and transparent. 
Microscopic examination showed in places that the air vesicles were full of cell débris, and that their walls were thickened and sometimes disorganised; in other places the lung tissue was entirely replaced by rounded cells of an indifferent type; and in yet other places all traces of organised structure was obliterated. In different places collections of round or irregularly round bodies could be seen, which stained deeply by Gram's method; and in which, when thus stained, no differentiation of structure - such as nucleus or cell membrane - could be made out. These bodies may or may not have been yeast cells, but, since no subcultures of yeast cells were obtained from the tissues, and since the bodies differed in their grouping from the arrangement which $I$ have observed in other cases in which yeast cells were undoubtedly present, I hesitate to express a definite opinion as to their nature. No bacteria were observed in the course of the microscopic examination. Numerous tubes of glucose agar were inoculated, and those from the fluid in the lung cavities, from the heart blood, and from the spleen remained sterile. Two tubes innculated from the liver each gave a culture of a coccus whose species was not identified. In Rat 4 the right lung was obviously enlarged somewhat beyond its natural size, and was converted into a lobulated mass of almost putty-like material, in which scarce any trace of normal lung tissue could be recognised by the naked eye. There was no actual pus in the lungs, but some parts were softer than others. There were no adhesions between the visceral and parietal pleura, nor between the contiguous surfaces of adjacent lobes. The left lung was less extensively diseased, containing only a few scattered caseous nodules. Microscopic examination failed to identify any of the Gramstaining bodies observed in the last case. Subcultures were made from the diseased lung tissue, and three species of bacteria were isolated-Staphylococcus pyogenes aureus, a bacillus resembling Proteus vulgaris, and a bacillus identical with Gürtner's Bacillus enteritidis. The Gärtner's bacillus was tested carefully on various media, and gave all the reactions; a rabbit inoculated with 0.5 c.c. of a forty-eight hours' old broth culture died in twenty-three hours, and a pure culture of the bacillus was obtained from its heart blood; a guinea-pig inoculated with a similar lose died at the end of twenty-four hours with an extensive blookly œdema at the site of inoculation, whilst a tame rat which received 0.25 c.c. of the same culture suffered from no obvious ill effects.

RAT 5 showed in both lungs a number of large yellowish-white nodules of softish material, but the diseased process was not so extensive as in Rat 4, and was fairly evenly distributed throughout both lungs. Patches of the lung tissue intervening between the nodules were pneumonic, and both lungs appeared to be considerably enlarged. The round Gram-staining bodies found in Rat 3 were again seen in this animal, and a Gärtner's bacillus, identical with that isolated from the lungs of Rat 4 , was found in this one also.

The bacteria found in the cases of Rats 4 and 5 were probably due to a secondary infection, and had no causative relation to the lesions present. In none of the rats were any morbid changes, other than those in the lungs, discovered; and the explanation of the lesions, whether due to the yeast inoculations or not, has yet to be found by further experiments.

Four white mice were inoculated with this yeast. Each received 0.1 c.c. of the yeast emulsion under the skin, and died between twenty and forty-eight hours after inoculation with a yeast septicæmia. Subcultures from the heart blood were made from three of the animals, and a pure culture of the yeast was obtained in each case. No gross morbid changes were observed.

This yeast, then, it will be seen, is actively pathogenic for tame mice and rabbits, pathogenic in a less degree for guinea-pigs, whilst its action on tame rats is still a matter of some doubt. 


\section{INTRAPERITONEAL INOCULATIONS.}

On referring to Table II., it will be seen that an intraperitoneal injection in the case of two rabbits (Nos. 13 and 14) was not followed by any obvious ill effect, in spite of the generally well-marked pathogenic action of the parasite for these animals, when the inoculation was made into the subcutaneous tissue, or into a muscle. Bearing in mind the careful experiments with $S$. cerevisice by Gilkinet, it was thought that the failure to infect in these two cases might be more than a mere accident, and might be due to some special protective activity of the peritoneal exudation. Experimental investigation as to this point has been commenced, but the experiments carried out are not yet sufficient in number for any definite conclusion to be drawn from them. They are, however, of interest, as showing that a very different kind of peritoneal reaction may follow the inoculation of different yeasts. Thus, guinea-pigs were inoculated in the peritoneal cavity with 1 c.c. of an emulsion made from a forty-eight hours' old culture of $S$. tumefaciens albus. An animal was killed two hours after the injection, and it was obvious that an active phagocytosis was in progress. The total number of yeast cells present in the exudation was probably considerably less than the number injected two hours previously. Some jeast cells were still free in the exudation, but many others were included within leucocytes. And of the included yeast cells some were still unaltered morphologically, whilst others were undergoing a rapid process of destruction. At the end of three hours there was still further obvious diminution of the number of yeast cells to be seen in a drop of the peritoneal exudation, and nearly all that could be seen were included within leucocytes, and many of these were in an advanced stage of disintegration, being merely represented by what appeared as a mass of granules within the leucocytes. Some of the larger lencocytes were seen to contain as many as three included yeast cells, of which two were usually quite young ones. During the earlier period after this intraperitoneal injection, it was found that there was a tendency for the yeast cells to run together in masses in the exudation. In a hanging-drop preparation of such peritoneal exudation, after two hours it was noticed that a number of the yeast cells showed a strong concentric differentiation of their contents. As a control experiment, a similar quantity of the red yeast (No. 10), used in the first series of experiments, was injected under exactly similar conditions. And in the peritoneal exudation, at the end of three hours, a very large number of the yeast cells were found; none were seen included in leucocytes. As to leucocytes themselves, very few were seen in the peritoneal exudation provoked by the injection of the red yeast; whereas, after the injection of $S$. tumefaciens albus, the peritoneal fluid was full of them. 


\section{The Axatomical Results of Yeast Infections.}

First, one may specially consider the results following infection with S. tumefaciens albus. The tumours formed at the site of inoculation, and the secondary nodules following a general infection, were histologically granulomata. When the primary tumour was situated in the subcutaneous tissue, it was usually free from any intimate connection with surrounding parts, and could be easily dissected out. When the injection was made into a muscle, the tumour could also be separated out from the surrounding fibres, but always with small pieces of the nuscle substance adhering to it in places. On microscopic examination it was seen that the tumour and nodules consisted of collections of round cells, all of which, so far as I have observed, were mononuclear; there was also a varying amount of homogeneous fibrinoid ground tissue throughout the formation. Rarely, what appeared to be very large tissue cells containing several yeast cells were seen. These large cells were apparently not multinuclear, and did not correspond morphologically with the typical "giant cell." In these granulomata one found in most cases an abundance of the yeast inoculated, and from them subcultures of the parasite on glucose agar were readily obtained.

\section{The Identification of S. tumefaciens alblis in the Tissues.}

The presence of the inoculated yeast in pure culture, both in the lesion at the site of inoculation and in the various secondary nodules in remote parts, having been proved beyond all doubt by culture experiments, the identification of the parasite in the tissues, by the ordinary methods of microscopic examination, remains to be considered. And my experience altogether agrees with that of previous investigators, who found that it is much easier to cletect the parasite in the fresh teased-out tissue than it is in hardened and stained sections.

On examining in glycerine and water a teased-out portion of a granuloma, produced in the course of an infection by $S$. tumefaciens albus, one olserves a number of budding, refractile bodies, which are readily recognised as the parasite. Some of these yeast cells are contained within the tissue cells, whilst others lie free between the latter. In such a specimen one finds round tissue cells which contain one, two, or three parasites; as a rule, however, a tissue cell only contains one such. The number of yeast cells recognisable in such a fresh specimen appears to largely exceed the number which are obvious in a section after hardening and staining. I have been in the habit of teasing out the tissues for examination in a normal saline solution, to which about 10 per cent. of glycerine has been added, and have not found any particular advantage in using a caustic potash solution for the purpose, as recommended by some. 
The lesions were also examined after hardening and staining ly various methols. For hardening, various solutions were used, and amongst those trienl were several clilutions of formalin, and of aleohol, and Flemming's, Muiller's, anl Foli's solutions. Whatever process, however, was userl, it wats olvions that, after hardening, the yeast cells becane more or less distorted, aud lost very much of the characteristic appearance observed when fresh specinens were examined. On the whole, a diluted formalin solntion appeared to cause the least amount of change.

The following were the staining methods fouml to le most useful :--

1. Gram's methol with auiline gentian-violet solutim was extensively used, but was a little uncertain for reasons given. In detail the following was the routine in staining. The section was first stainel with gentian-violet for ten minutes, then dipued into water, then placel in Gram's ioline solution for two nimutes, am fiually decolorised in alsolute alcohnl in the usual mamer. The comnterstaining was done with either eosin or Bismarck-hrown solutions, and the sections were then cleared with celar oil aud xylul.

Now, although a pure culture of $S$. tumefacions albus stains very deeply when treated hy this methorl, a certain anomnt of variation was met with in the ease of the yeast cells as they oceurred in the tissues. It seemed certain that many of the yeast cells, prohally hecause of legenerative changes, had entirely lost their power of retaining the stain after a thorough washing in the alcohol, of such cluration, however, that it would not have affected the staining of a fresh, pure sulture.

2. With Löffler's methylene-l)lue solution a clistinct contrast staining was often olserved, hut with this again some varialility was noticel. The best results were olitained by staining for five or six minutes, folkowed by a rather prolonged washing with distilled water. Under these conditions many of the yeast cells stained with a distinct reddish cinge, which formed a gool contrast to the pure blue of the tissue staining.

3. Some very good contrast staining of a similar sort was also obtained by using a 1 per cent. methyl-violet aqueous solution. Sections were stained in this for fom minutes, and suljected to a prolonged washing in distilled water. The yeast cells then appeared of a rich purple hue, which again stool out in goul contrast with the rest of the section. But, with any of these three methols, it was quite obvious that a large number of the yeast cells were not hrought into evidence, and in many of the munerons sections examined it would have been quite impossible to illentify yeast cells with any degree of certainty had one been compelled to rely on the aplearances in these sections alone. More particularly was this the case with secondary nodules. For in these the characteristic "psendo-mycelial" forms, 
which will be referred to further on, were not net with, but the parasite occurred in "yeast" form, and for the most part as simple cells; when, however, such cells happenerl to be in the act of burking, their ilentitication was, of course, simplitied. Various other methods were tried, but none proved satisfactory. Sanfelice's special staining methol with safranin and malachite-green was carefully carried out, aceording to the directions griven, hut failed to work satisfactorily in my hands. Prolonged efforts were also narle to utilise osmic acid for the differentiation of yeast cells from the tissue cells, but with this agrain no reliable results were obtained. The difficulty of identifying the parasite in stained tissues depeuts partly ou the loss of characteristic shape which oceurs during the hardening process, and partly upon changes, probahly of a degenerative character, which the yeast cells aprear to molergo rapidly after they hecome encelosed within the gramulomata. The difficulty is enlanced by the fact that the stains which seem hest allapted for demonstrating the yeasts are also those which have a strong affinity for the nuclei of the tissue cells. With regard to the form of the parasite, as it was seen in sections, the following olservations were malle. A considerable proportion of the yeast cells which could be stained in sections of the primary tumour were much altered from their nomal shape. This alteration was due, as alrealy suggested, partly to degenerative changes and partly to the action of the harlening fluid. "Pseu(1)-mycelial" forms were frequently met with; these had the alpearance of longer or shorter, irregulirly-contoural himls, in which only a constriction here and there indicated the origin of the band in a continuous chain of yeast cells. That these bands were "pseudo-mycelial" and not a true mycelium was proved hy the fact that various intermediate stages between such a cylindrical band and short chains of fairly normal yeast cells could be seen (Plate IV. Fig. 4). These bands were never very long, and problibly seldom represented more than three or four individual cells. From some of the bands hrauching outgrowths had heen produced by lateral budding of one or other of the yeast cells forming the parent band. Pesides these bands, numerous other forms of degenerative irregular shape, representing single cells, were seen; a crescentic shaje was a type commonly met with. Then, again, small masses of amorphous, deeply-staining material represented apparently the last stage of disalpearing yeast cells. The secondary nodules met with were apparently of much later formation than the primary tumour in the same case, and in them no pseurlo-mycelial forms were met with. They contained only single cells, butding cells, and occasionally two adult cells lying side by side. Degenerative forms were less common in them than in the primary tumour. In the majority of the stained yeast cells but little differentiation of structure could be seen when sections were examined with the microscope in the ordinary way. But when, for photographic purposes, the enlarged picture of a section was thrown upon the 
focussing plate of a cinera, a very distinct capsule and a concentric arrangement within the yeast cells could frequently he seen.

The foregoing remarks as to the anatomical characters of the lesions, and as to the applearance of the yeast cells in the tissues, are founded more particularly on a study of $S$. tumefacions albus. The tumours at the site of moculation with the yeasts used in Series I. had, however, the same general structure in every case. The uncertainty of Gram's method of staining for the identification of the yeast cells, and the advantage of examining the freshly teasel-unt tissue, were equally apparent in the first as in the second series of experiments. No morphological distinction between one species of yeast and another conkl be made ont in the stained sections.

\section{The Theory of the Blastomicetic Causation of Malignant DISEASE.}

When dealing with the question of the pathogenic action of yeasts, it is impossible tis avoid reference to the theories as to the causation of malignant disease, which have been advanced by Sanfelice and Roncali to mention the two most prominent pathologists who have interested themselves in this matter. The theories advanced had for their foundation the suyposition that certain bodies, which could be seen included within the cells of carcinoma, were yeast cells. And the supposition was in turn supported by evidence which, founded as it was upon certain histological aplearances seen in cancer cells, when treated hy virions methouls, nust be dismissed as alsolutely inadequate. $\mathrm{Up}_{\mathrm{p}}$ to this point, the newer theories as to cancer formation had merely changed to "yeast cells" the names of certain bodies described by Russell as "fnchsin bodies," and by various other observers-and more especially in commection with this aspect of the question, one maly mention Armand Ruffer and Plimmer-as protozoa. And considerably more evidence than is now available must be bronght forward before one can form any opinion as to whether the "fuchsin bodies" are merely differentiated but integral parts of the cancer cells themselves, or whether they are of the niture of animal or regetable parasites, protozon or blastemyeetes as the case may be.

Quite recently, however, there have heen sugrestions of further evidence of a rather more detinite chancter from both sanfelice and Roncali. Thus the former brietly reports, that by the inoculation of $S$. neoformuns he has at last been able to produce a typical "aleno-carcinoma" in the namma of a bitch and in the testicle of a dog. sanfelice merely records $\left({ }^{2 s}\right)$ his results, and promises exact letails in a further paper, a paper which is awaited with great interest by all pathologists. Tincali $\left({ }^{21}\right)$ published almost simultaneously with sanfelice a paper in which he describes a yeast, Blastomyces vitro simile deycnerans, isolated from a case of "adeno- 
carcinoma" of the colon, and notes that he has isolated the same yeast from three such different cases of malignant disease as the one under consideration, an epithelioma of the tongue, and a sarcoma of the mamma. Inoculation of guinea-pigs with this yeast resulted in the formation of granulomata only.

It is impossible to discuss this question at any further length now. From evidence available, one can only say that it is not improbable that some, at anyrate, of the cases which are now on clinical and histological grounds classified amongst sarcomas, may prove to be really cases of yeast infection. But as to the exact causation of carcinoma we are still absolutely ignorant.

[My acknowledgments are due to the Council of the British Institute of Preventive Medicine for facilities afforded for carrying out much of the work referred to in the foregoing paper.]

\section{BIBLIOGRAPHY.}

1. Bernard . . . . Arrh. gin. de méd, Paris, 1848 , tome xiv.

2. Grohe . . . . . . Berl. klin. Wchnschr., 1870, S. 9.

3. Popoff . . . . . . Ilida, 1872, S. 513.

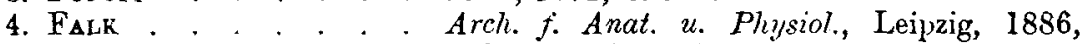
Suppl. Bd. S. 17.

5. TELMAYER

"Untersuch, ueber die Wirkungen der Verscheidenen Hefearten auf den thierischen und menschlichen Organismus," Arch. $f$. Hyg., München u. Leipzig, 1891, Bd. xii.

6. RAUM . . . . . . . Ztschr.f. Hyg., Leipzig, 1891, Bd. x.

†. Grawitz . . . . Deutsche Ztschr. f. praht. Med., Leipzig, May 1877 , and elsewhere.

8. Klemperer . . . . "Ueber die Natur des Soorpilzes," Centralbl. f. Klin. Med., Bonn, 1885 .

9. G. Roux And Lrnossier . "Recherches morphologiques sur le champignon du Muguet; Recherches biologiques sur le champignon du Muguet,"Arch. de méd. expér. et d'anat. piath., Paris, 1890, tome ii.

10. Tessier

"Contribution a l'étude du champignon du Muguet," ibial, 1897, tome iii.

11. Payne.

12. ARtault

"Manual of General Pathology," 1888, p. 593.

"Flore et faune des cavernes pulmonaires," Arch. de parasitol., Paris, 1898, tome i. No. 3.

13. GRASSET

"Fitude d'un champignon pyogène parasite de l'homme," Arch. de méd. expér. et d'anat. path., Paris, 1893, tome v.

14. Troisier and Achatye " "Sur un angine parasitaire causée par une levure et cliniquement semblable au Muguet," ibid., 1893, tome v.

15. Gilchrist

"A Case of Blastomycetic Dermatitis in Man," Johns Hopkins Hosp. Rep., Baltimore, 1896 vol. i.

16. Busse

"Ueber parasitaire Zelleinschlusse und ihre Zuchtung," Centralul. f. Bakteriol. u. Parasitenћ, Jena, 1894, Bd. xvi.; "Die Hefen ais Krankheitserreger," Berlin, 1897. 
17. Curtis,

"Note sur un parasite végetale de l'espèce des levures produisant des tumours d'aspect myxomateux chez l'homme," Presse méd. belge, Bruxelles, 1895, p. 370; "Contribution a l'étude de la saccharomycose humaine," Ann. de l'Inst. Pasteur, Paris, 1896, tome x.

18. Gilchrist and Stokes . "A Case of Pseudo-Lupus Vulgaris caused by a Blastomyces," Journ. Exper. Med., N. Y., 1898 , vol. iii.

19. De Srmoxi . . . . "Ueber das Verkommen von Blastomyceten in der hypertrophischen Tonsille," Centralbl. f. Balteriol. u. Parasitenk., Jena, 1897, Bd. xxii.

20. Maffucci axd Sirleo. . "Ueber die Blastomyceten als Infectionserreger bei bösartigen Tumoren," Ztschr. f. Hyg., Leipzig, 1898, Bd. xxvii.

21. Tokishige

"Ueber pathogene Blastomyceten," Centralbl. f. Bakteriol. u. Parasitenk., Jena, 1896, Bd. xix.

22. Follertor . . . . . "On the Pathology of some Infective Granulomata in Horses and Cattle," Journ. Comp. Path. and Therap., Edin. and London, 1898, vol. xi. p. 2.

23. Fermi and Aruch . . . "Ueber die Natur des sogenannten Cryptocaccus farcininosus Rivolta," Centralbl. f. Bakteriol. u. Parasitenk, Jena, 1895, Hh. xvii.

24. SANFELICE

"Ueber eine für Tiere pathogene Sprosspilzart," Centralbl. $f$. Bakteriol. u. Parasitenk., Jena, 1895, Bd. xvii.; "Ueber einen neven pathogenen Plastomyceten," ibid., 1895, Bd. xviii. ; "Ueber die pathogene wirkung der Blastomyceten," Ztschr. $f$. Hyg., Leipzig, 1895-6, 13d. xxi. and xxii.

25. RABINOWITSCH

"Untersuch. ueber pathogene Hefearten," Ztschr.f. Hyg., Leipzig, 1895, Bd. xxi.

26. Ginkinft. . . . . "Recherches sur le sort des levures lans l'organisme," Arch. de méd. exper. et d'anat. path., Paris, 1897, tome ix.

27. JoNA . . . . . "Die Schutznittel des organismus gegen Blastomyceten," Centrallul. f. Bakteriol. $u$. Parasitenk, Jena, 1897, Bd. xxi.

28. Sanfelice, . . . . . "Ein weiterer Beitrag zur Aitiologie der bïsartigen Geschwulste," Centralbl. $f$. Batiteriol. u. Parasitenk., Jena, 1898, Bd. xxiy.

29. RoNCALI, .

"Klinische Beobachtung und histologische Untersuchungen veber einen Fall von primären Adino-carcinom (Papilloma infectans) des colon transversum und descendens mit sekündaren Uebergang auf das grosse Netz und das Mesenterium," ibid.

30 Nesczadimeno, . . . . "Zur Pathogenese der Blastomycetes," Centralbl. f. Bakteriol. u. Parasitenk., Jena, 1899, Bd. xxv. 


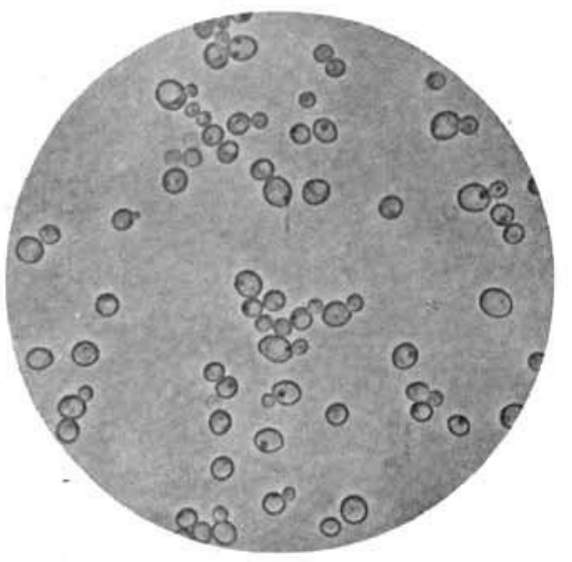

FIG. 1.

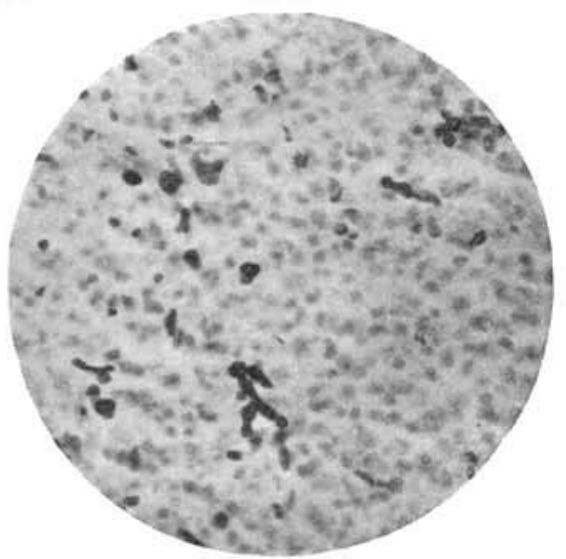

FIg. 4.

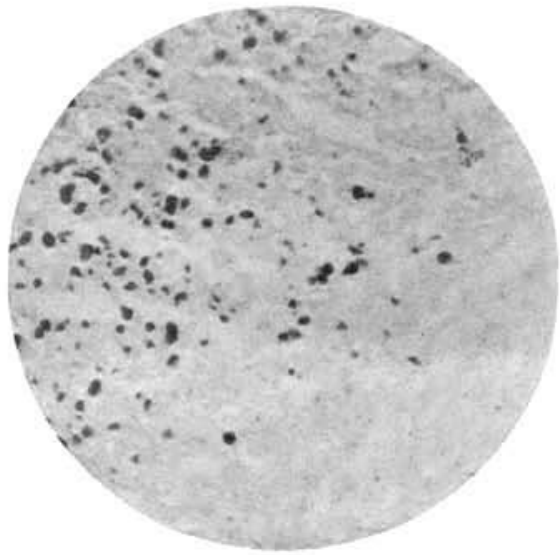

Frg. 6.

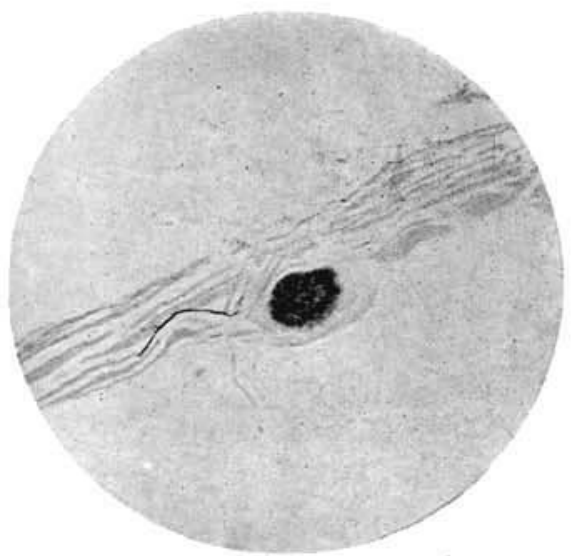

Fig. 3.

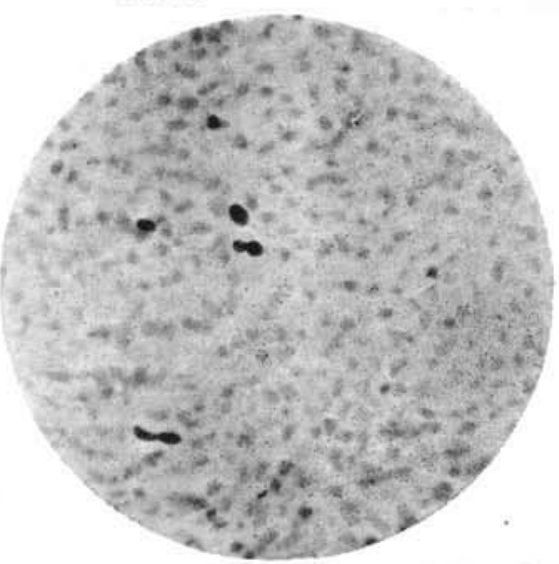

Fig. 5 .
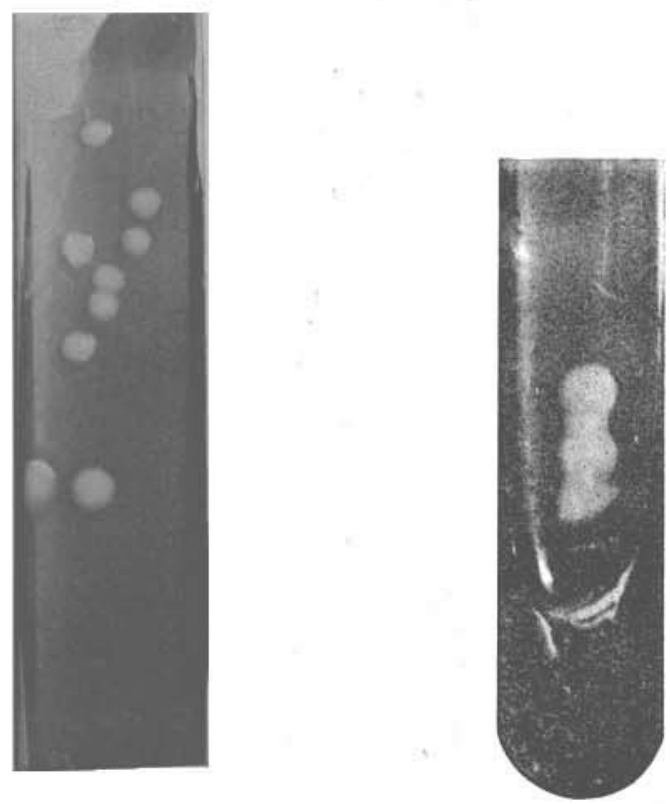

FIG. 7 .

FIg 8. 
31 Galli-VAlekio,. . . . "Sur une variété d'Oidium albicans, isolée des selles d'un enfant atteint de gastroentérite chronique," Arch. de parasitol., Paris, 1898, tome i. No. 4.

\section{DESCRIPTION OF PLATE IV.}

FIG. 1. - S. tumefaciens albus, living culture $(\times 600)$. From subculture, twenty-four hours old, on glucose agar, direct from liver nodule in Rabbit 5, Series II.

FIG. 2.-Tumour at site of inoculation, abont half natural size. From Rabbit 11, Series II.

FIG. 3. -Section through nodule on diaphragm ( $\times 20$ ). From Rabbit 5, Series II., stained with methylene.blue and eosin.

FIfs. 4.-Section through tumour at site of inoculation $(\times 600)$. From Rabbit 5, Series II. Stained with methyl-violet.

Fig. 5.-Another section through same tumour $(\times 600)$. From Rabbit 5, Series II. Stained with inethylene-blue.

FIG. 6. - Section throngh nodule on diaphragm $(\times 600)$. From Rabbit 5, Series II. Stained by Gram's method, couniterstained with eosin.

FIG. 7.--Subculture of S. tumefaciens albus direct from tumour at site of inoculation (about natural size). From Rabbit 5, Series II. Forty-eight hours' growth on glucose agar.

FIG. 8. - Subculture of $S$. tumefaciens albus, direct from nodule in liver (about natural size). From Rabbit 5, Series II. Forty-eight hours' growth on glucose agar.

(The specimens from which these photographs were taken were shown and described in the discussion on "Pseudo-Tuberculosis," at the Pathological Society of London, on' 21st February and 7 th March 1899.) 